\title{
PKM Pengolahan Batang dan Pelepah Pohon Pisang untuk Peningkatan Ekonomi Masyarakat Desa Pakuniran, Kecamatan Pakuniran
}

\author{
Wahab Sya'roni ${ }^{1}$, Indah Sri Mulyati ${ }^{2}$, M. Noer Fadli Hidayat ${ }^{3}$ \\ Universitas Nurul Jadid, Paiton ${ }^{123}$ \\ \{indahsrimulyati001@gmail.com¹,wahab@unuja.ac.id², fadli@unuja.ac.id ${ }^{3}$ \}
}

\begin{tabular}{ll}
\hline \multicolumn{1}{c}{ Submission: 29/11/2021 Received: 31/12/2021 Published: 31/12/2021 } \\
\hline Keywords: & Abstract. Pakuniran village is one of villages in Probolinggo regency \\
Banana Stems, & that has many natural resources of banana trees. Banana trees are \\
Banana Midribs, & only used the fruit for sale or make as chips, while banana stems \\
Economic & and midribs considered as waste and just thrown away. That's \\
Improvement3 & unfortunately because if it's process as well could give economic \\
& income for Pakuniran villagers. Because of that students of Nurul \\
& Jadid University give socialization and training to process banana \\
& stems and midribs. So that formed a group of housewives who \\
& could produce and market processed products from banana stems \\
& and midribs as banana stems juice and banana midribs chips and \\
& produce hand sanitizer of banana midribs to increase community \\
& efforts to prevent covid-19 virus.
\end{tabular}

Katakunci: $\quad$ Abstrak. Desa Pakuniran merupakan salah satu desa di Kabupaten Batang Pisang, Probolinggo yang memiliki sumber daya alam berupa pohon pisang Pelepah Pisang, yang melimpah. Pohon pisang ini hanya dimanfaatkan buahnya Peningkatan untuk dijual secara langsung atau dibuat sebagai keripik, sedangkan Ekonomi batang dan pelepah pisang dianggap sampah dan dibuang begitu saja. Hal ini sangat disayangkan karena jika diolah dengan baik batang dan pelepah pisang dapat memberikan peningkatan ekonomi bagi warga desa Pakuniran. Oleh karena itu mahasiswa Universitas Nurul Jadid memberikan sosialisasi dan pelatihan untuk membuat olahan dari batang dan pelepah pisang ini Sehingga terbentuklah kelompok ibu-ibu rumah tangga yang dapat memproduksi dan memasarkan produk olahan dari batang dan pelepah pisang berupa jus batang pisang dan keripik pelepah pisang serta menghasilkan hand sanitizer alami dari pelepah pisang untuk meningkatkan upaya masyarakat untuk mencegah virus covid-19.

\section{Pendahuluan}

Batang dari pohon pisang memiliki khasiat yang berbeda, yaitu untuk menyembuhkan sakit kencing yang panas dan menawarkan keracunan warangan yang dapat disembuhkan dengan perasan air dari batang pisang ini (Daryanto, 2003). Selain itu batang pisang kering juga dapat digunakan sebagai bahan baku membuat tali yang cukup kuat untuk kepeluan sehari- 
hari. Kini dengan teknik sederhana, pelepah batang pisang bisa dimanfaatkan sebagai bahan baku kerajinan dan keterampilan tangan yang menarik (Nani Rosana Erman, 2007). Dalam pertanian batang pisang dapat dimanfaatkan sebagai pupuk kompos. Sementara dalam bidang perikanan, dapat digunakan sebagai campuran dan media dalam budidaya belut (Bambang Cahyono, 2009).

Pelepah pisang juga diketahui mengandung tiga zat sebagai anti bakteri, yaitu saponin, flavonoid, dan asam askorbat (Ariningsih, dkk 2015). Kandungan saponin dan tannin pada pelepah pisang diketahui dapat dijadikan sebagai zat anti septik alami. Hasil penelitian menunjukkan bahwa terdapat zona hambat pada konsentrasi 20\%, 40\%, 60\%, dan 80\% (Fadhilah, 2017).

Pohon pisang merupakan salah satu potensi sumber daya alam yang ada di desa Pakuniran, selama ini warga desa Pakuniran hanya memanfaatkan pohon pisang untuk dijual buahnya secara langsung maupun dibuat sebagai keripik, sedangkan untuk batang dan pelepah pohon pisangnya dibuang begitu saja karena dianggap tidak berguna. Padahal jika diolah dengan baik dapat dihasilkan makanan, minuman, dan hand sanitizer yang berguna untuk peningkatan ekonomi dan menjadi upaya masyarakat dalam mencegah virus covid-19. Pohon pisang untuk membuat handsanitizer bisa dari jenis pohon pisang apa saja tanpa kriteria khusus, begitu juga sebagai minuman, dan untuk olahan makanan pohon pisang yang dibutuhkan adalah pohon pisang kepok maupun pisang lain yang tidak memiliki terlalu banyak serat. Untuk jenis batang pisang lain jika diolah sebagai makanan maka akan terasa kurang enak karena pahit.

Desa Pakuniran memiliki luas tanaman buah pisang sebanyak 0.5 ha dengan hasil tanaman buah pisang sebanyak 1 ton/ha. Desa Pakuniran memiliki luas 858.200 dengan luas tanah sawah 142,20. Jumlah penduduk desa Pakuniran adalah 5.170 dengan kepadatan 603. 
Table 1. Area of Sub-district per Village

\begin{tabular}{|c|c|c|c|c|}
\hline Number & Village & Dry Soil & Wet nd & Amount \\
\hline 1. & Ranon & 116000 & 489700 & 605700 \\
\hline 2. & Kedung Sumur & 37000 & 1997200 & 2034200 \\
\hline 3. & $\begin{array}{l}\text { Gunggungan } \\
\text { Kidul }\end{array}$ & 138500 & 1459500 & 1598000 \\
\hline 4. & Kalidandan & 12000 & 1726500 & 1738500 \\
\hline 5. & Blimbing & 5700 & 456500 & 462200 \\
\hline 6. & Gondosuli & 150000 & 918500 & 1068500 \\
\hline 7. & Kertonegoro & 40000 & 562500 & 602500 \\
\hline 8. & Bimo & 63000 & 402500 & 465500 \\
\hline 9. & Pakuniran & 142200 & 716000 & 858200 \\
\hline 10. & Patemon Kulon & 50300 & 267700 & 318000 \\
\hline 11. & $\begin{array}{l}\text { Gunggungan } \\
\text { Lor }\end{array}$ & 88500 & 61000 & 149500 \\
\hline 12. & Sogaan & 167400 & 106200 & 273600 \\
\hline 13. & Sumberkembar & 134300 & 41000 & 175300 \\
\hline 14. & Alas Pandan & 94500 & 103500 & 198000 \\
\hline 15. & Bucor Wetan & 237000 & 131000 & 368000 \\
\hline 16. & Bucor Kulon & 132500 & 102500 & 235000 \\
\hline 17. & Glagah & 178300 & 139500 & 317800 \\
\hline \multicolumn{2}{|c|}{ Amount in 2018} & 1787200 & 9681300 & 11468500 \\
\hline \multicolumn{2}{|c|}{ Amount in 2017} & 1787200 & 9681300 & 11468500 \\
\hline \multicolumn{2}{|c|}{ Amount in 2016} & 1793900 & 9685300 & 11479200 \\
\hline
\end{tabular}

Sumber: Registrasi, https://probolinggo.bps.go.id

Di dalam Badan Pusat Statistik Probolinggo jumlah keluarga pra sejahtera lebih banyak yakni 1005 orang dibandingkan keluarga yang sejahtera yakni 700 orang, jumlah tenaga kerja 2317 orang dari jumlah penduduk sebanyak 3285 orang.

Table 2. Population According to the Density of Registration Result

\begin{tabular}{clrrr}
\hline Number & \multicolumn{1}{c}{ Village } & Wide $(\mathrm{km} 2)$ & Population & Density \\
\hline 1. & Ranon & 6,06 & 2.843 & 469 \\
\hline 2. & Kedung Sumur & 20,74 & 1.015 & 49 \\
\hline 3. & $\begin{array}{l}\text { Gunggungan } \\
\text { Kidul }\end{array}$ & 16,07 & 2.974 & 185 \\
\hline 4. & Kalidandan & 17,38 & 972 & 56 \\
\hline 5. & Blimbing & 4,62 & 1.155 & 250 \\
\hline
\end{tabular}




\begin{tabular}{clrrr}
\hline 6. & Gondosuli & 10,74 & 4.775 & 445 \\
\hline 7. & Kertonegoro & 5,06 & 1.001 & 198 \\
\hline 8. & Bimo & 4,65 & 1.252 & 269 \\
\hline 9. & Pakuniran & 8,58 & 5.170 & 603 \\
\hline 10. & Patemon Kulon & 3,20 & 1.148 & 359 \\
\hline 11. & Gunggungan Lor & 1,49 & 2.005 & 1.346 \\
\hline 12. & Sogaan & 167400 & 106200 & 273600 \\
\hline 13. & Sumberkembar & 134300 & 41000 & 175300 \\
\hline 14. & Alas Pandan & 94500 & 103500 & 198000 \\
\hline 15. & Bucor Wetan & 237000 & 131000 & 368000 \\
\hline 16. & Bucor Kulon & 132500 & 102500 & 235000 \\
\hline 17. & Glagah & 178300 & 139500 & 317800 \\
\hline Amount in 2018 & 1787200 & 9681300 & 11468500 \\
\hline Amount in 2017 & 1787200 & 9681300 & 11468500 \\
\hline Amount in 2016 & 1793900 & 9685300 & 11479200 \\
\hline
\end{tabular}

Sumber: Registrasi, https://probolinggo.bps.go.id

Oleh sebab itu usaha peningkatan perekonomian masyarakat desa Pakuniran harus diselenggarakan. Mata pencaharian penduduk sangat beragam yakni bertani, beternak, berdagang, dll. Rata-rata pendidikan di desa Pakuniran terbanyak yakni 1802 orang hanya tamat SD/Sederajat. Dari data diatas dapat ditarik kesimpulan bahwa rata-rata masyarakat desa Pakuniran belum dapat memaksimalkan pemanfaatan pada pohon pisang karena kurangnya pemahaman masyarakat, kami tim Program Pembinaan dan Pemberdayaan Desa (PHP2D) Universitas Nurul Jadid melakukan sosialisasi dan pelatihan untuk memanfaatkan batang dan pelepah pisang ini secara maksimal sehingga menjadi salah satu cara agar ekonomi masyarakat desa Pakuniran meningkat.

Table 3. The Average Level Education of the Pakuniran Villagers

\begin{tabular}{lll}
\hline Number & Description & Amount \\
\hline 1. & Not School yet & 127 \\
\hline 2. & Have been Elementary School but Haven't Finished & 67 \\
\hline 3. & Graduated from Elementary School/Equivalent & 1802 \\
\hline 4. & Graduated from Junior High School/Equivalent & 842 \\
\hline 5. & Graduate from High School/Equivalent & 359 \\
\hline 6. & Graduated S1 & 88 \\
\hline
\end{tabular}

Sumber: http://pakuniran.desa.id, diakses pada tanggal 07 April 2021 
Hasil dari kegiatan ini adalah bertambahnya ilmu pengetahuan masyarakat terkait pemanfaatan pohon pisang, cara mengolah pohon pisang sebagai makanan, minuman, dan hand sanitizer serta cara memasarkan produk. Terbentuknya kelompok ibu-ibu rumah tangga yang mampu memproduksi aneka olahan dari batang dan pelepah pohon pisang ini serta menghidupkan kembali kegiatan-kegiatan PKK yang sudah tidak produktif.

\section{Metode}

Metode kegiatan Pengabdian Kepada Masyarakat (PKM) ini adalah melakukan pelatihan dan pendampingan ini dilakukan di desa Pakuniran tepatnya di Dusun Duren. Sosialisasi pertama membahas tentang manfaat pengolahan batang dan pelepah pisang serta pelatihan pembuatan keripik dari pelepah pisang sedangkan, sosialisasi tahap kedua membahas tentang pembuatan jus batang pisang dan hand sanitizer dari pelepah pisang. Berikut gambar tahapan-tahapan program pelaksanaan kegiatan PKM.

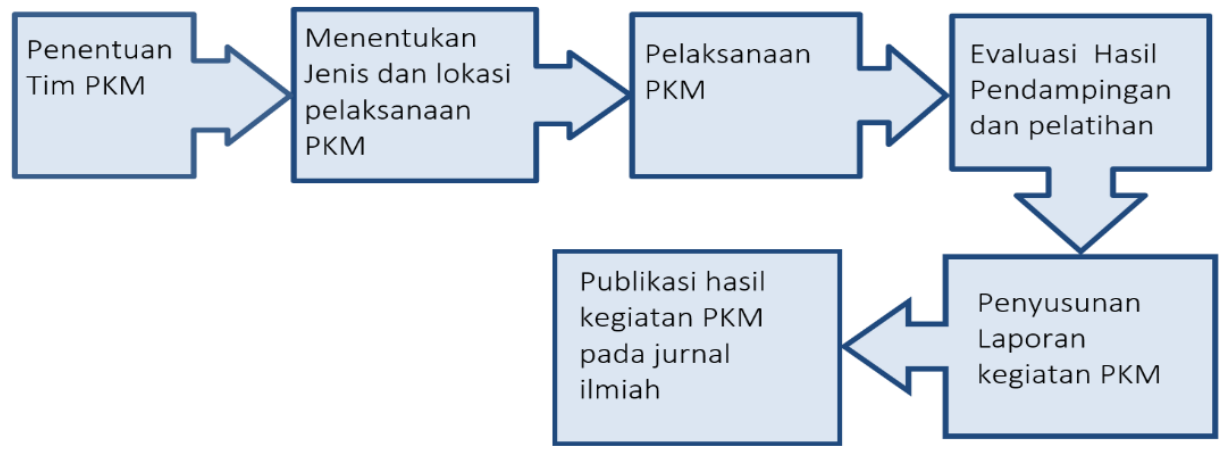

Gambar 1. Tahapan Pelaksanaan Pengabdian Kepada Masyarakat (PKM)

Penjelasan mengenai setiap tahapan kegiatan Pelaksanaan Pengabdian kepada Masyarakat (PKM) sebagai berikut:

1. Pembentukan Tim PKM dilakukan melalui musyawarah dan diskusi dengan 12 orang mahasiswa program studi Rekayasa Perangkat Lunak Universitas Nurul Jadid yang terdiri dari mahasiswa angkatan tahun 2018 dan 2019. Pembentukan tim dilakukan secara online melalui google meet mengingat jauhnya lokasi semua mahasiswa.

2. Tim PHP2D PKM menentukan materi pendampingan dan pelatihan serta melakukan pemetaan sasaran peserta sosialisasi dan pelatihan 
secara merata dan menyeluruh serta penentuan tempat dan lokasi kegiatan PKM yang sesuai dengan tema dan materi agar tepat sasaran.

3. Pelaksanaan kegiatan PKM di Desa Pakuniran tepatnya di Dusun Duren dilakukan dengan pemberian informasi tentang manfaat batang dan pelepah pisang serta cara mengolahnya sehingga bisa dijadikan aneka produk yang bernilai jual.

4. Melakukan evaluasi terhadap semua target kegiatan PKM.

5. Penyusunan laporan kegiatan PKM sebagai bukti pertanggungjawaban program.

6. Publikasi kegiatan pengabdian kepada masyarakat dalam jurnal ilmiah yang bertujuan untuk menambah referensi ilmiah yang terkait dengan pelaksanaan pengabdian kepada masyarakat khususnya teknik sosialasasi.

\section{Hasil}

Sebagai wujud membantu pemerintah dalam hal peningkatan ekonomi masyarakat yang masuk ke dalam Program Holistik Pembinaan dan Pemberdayaan Desa serta ikut serta dalam membantu pencegahan covid-19, maka target dan luaran yang dihasilkan dari kegiatan Pengabdian kepada Masyarakat ini dapat dilihat pada Tabel berikut. 
Tabel 4 Target dan luaran program pengabdian

\section{Target}

1. Memberikan sosialisasi terkait manfaat dari batang dan pelepah pohon pisang serta cara mengolah batang dan pelepah pisang sebagai produk antiseptik berupa hand sanitizer, keripik pelepah pisang, dan jus batang pisang.

2. Memberikan sosialisasi, pelatihan, dan pendampingan kepada warga desa Pakuniran tepatnya di Dusun Duren untuk membuat hand sanitizer alami dari pelepah pisang dan campuran kayu manis

3. Memberikan pelatihan kepada warga desa Pakuniran tepatnya di Dusun Duren untuk membuat keripik pelepah pisang dan jus batang pisang

4. Melakukan pendampingan dengan membentuk kelompok khusus untuk memproduksi olahan dari batang dan pelepah pisang

5. Membuat media tentang programprogram yang telah terlaksana melalui berbagai media sosial seperti Instagram, facebook, dan lain sebagai.

6. Kemampuan warga masyarakat untuk melakukan pemasaran produk

7.

8. Menumbuhkan rasa gotong royong warga masyarakat

\section{Luaran}

1. Pemahaman warga desa Pakuniran khususnya Dusun Duren bahwa pelepah dan batang pisang jika diolah akan menghasilkan produk yang bermanfaat dan jika dikelola dengan serius dapat menjadi jalan untuk peningkatan ekonomi masyarakat.

2. Pemahaman warga desa Pakuniran khususnya Dusun Duren untuk membuat hand sanitizer alami dari pelepah pisang guna mencegah penularan covid-19 sekaligus jika diproduksi dalam skala besar dan dikembangkan bisa dipasarkan guna meningkatkan perekonomian warga desa

3. Pemahaman warga desa Pakuniran khususnya Dusun Duren untuk mengolah pelepah dan batang pisang sebagai olehan makanan dan minuman, jika sudah diproduksi dalam skala besar dan dikelola dengan serius dapat memberikan dampak pada peningkatan ekonomi masyarakat

4. Terbentuknya kelompok usaha mikro dan sedang untuk pengolahan batang dan pelepah pisang

5. Berbagai macam media tentang terlaksananya program baik berupa foto maupun video kegiatan

6. Warga desa dapat belajar dan didampingi bersama-sama dengan tim PHP2D cara memasarkan produk olahan

7. Bersama dengan warga desa Pakuniran bergotong royong memperbaiki tempat untuk produksi dan penjualan

Dalam mencapai target dan luaran yang sudah ditetapkan dalam kegiatan PKM ini maka tim PKM bersama mitra-mitra terkait melakukan kegiatan sesuai dengan tahap-tahap sebagai berikut: 


\section{Penentuan Tim}

Agar kegiatan berjalan dengan baik maka perlu diadakan pembentukan tim yang sesuai dengan kompetensi masing-masing untuk mengatasi atau menemukan solusi permasalahan ketika kegiatan. Pembentukan tim dilakukan dengan cara musyawarah dan diskusi secara online melalui google meet. Ada anggota tim yang bertugas dalam pencarian data melalui studi literatur dan ada anggota tim yang melakukan survei langsung ke lapangan. Hasilnya yakni membandingkan ketepatan antara data yang sudah ditemukan melalui studi literatur dengan data dilapangan, dari hasil perbandingan ditemukan data yang relevan bahwa di desa Pakuniran memang memiliki potensi sumber daya alam berupa pohon pisang yang melimpah, terbukti dengan di sepanjang jalan, di perkebunan warga, di pekarangan depan maupun dibelakang rumah warga desa Pakuniran ditanami pohon pisang.

Selain itu juga melakukan wawancara dengan beberapa warga desa terkait potensi pohon pisang yang ada di desa Pakuniran ini dan pemanfaatan apa saja yang dilakukan oleh warga dari pohon pisang. Warga desa menjelaskan bahwasannya pohon pisang sangat melimpah namun mereka tidak tahu jika batang dan pelepah pisang dapat diolah sebagai beraneka produk sehingga batang dan pelepah pisang ini sering dibuang begitu saja. Warga desa hanya sering mengambil buah pisangnya untuk dijual secara langsung maupun menjadikannya sebagai keripik pisang.

\section{Penyusunan Materi dan Penentuan Lokasi}

Penyusunan materi dilakukan dengan diskusi atau musyawarah antar anggota tim. Masing-masing anggota memberikan pendapat tentang materi yang akan disampaikan serta isi dari materi tersebut hasil dari musyawarah dalam mufakat tersebut digunakan untuk susunan materi, materi dibuat dengan menggunakan slide yang menarik agar tidak bosan dalam hal penyusunan materi ini diserahkan kepada mahasiswa program studi Rekayasa Perangkat Lunak Universitas Nurul Jadid angkatan 2019 namun masih tetap didampingi oleh angkatan 2018.

Izin dilakukan oleh perwakilan tim PHP2D kepada pihak-pihak terkait, seperti PJ desa Pakuniran, Carik, dan lain-lain. Tim PHP2D izin untuk mengadakan kegiatan pengolahan batang dan pelepah pohon pisang di desa Pakuniran. Hasil dari perizinan ini adalah izin dari PJ desa Pakuniran untuk 
melakukan kegiatan sosialisasi dan pelatihan serta penentuan lokasi. Penentuan lokasi untuk kegiatan sosialisasi dan peltihan yang didapatkan dari hasil diskusi dan musyawarah bersama perangkat desa di balai desa Pakuniran yang saat itu dihadiri oleh PJ Desa Pakuniran dan beberapa perangkat desa yang lain, mereka mengusulkan untuk kegiatan dilakukan di desa Pakuniran, Dusun Duren karena mempertimbangkan beberapa hal seperti alat atau barang yang dipersiapkan agar lebih mudah dibawa sebab ada beberapa alat dari desa Pakuniran yang menyediakan seperti alat masak. Setelah melakukan musyawarah tersebut maka diputuskan untuk mengadakan kegiatan sosialisasi dan pelatihan di kediaman Bapak Carik Desa Pakuniran yang berada di Dusun Duren.

Untuk pengumpulan peserta sosialisasi dan pelatihan dibantu oleh Bapak Carik desa Pakuniran, mengingat masih masa pandemi tidak bisa mengumpulkan banyak peserta dan wajib mematuhi protokol kesehatan maka kegiatan ini hanya dihadiri 25 orang di sekitar desa Pakuniran tepatnya di Dusun Duren. Dengan memakai masker, face shield, dan memakai hand sanitizer. Selain itu jumlah peserta yang 25 orang ini guna memfokuskan dan memaksimalkan pemberdayaan sumber daya manusia di desa Pakuniran.
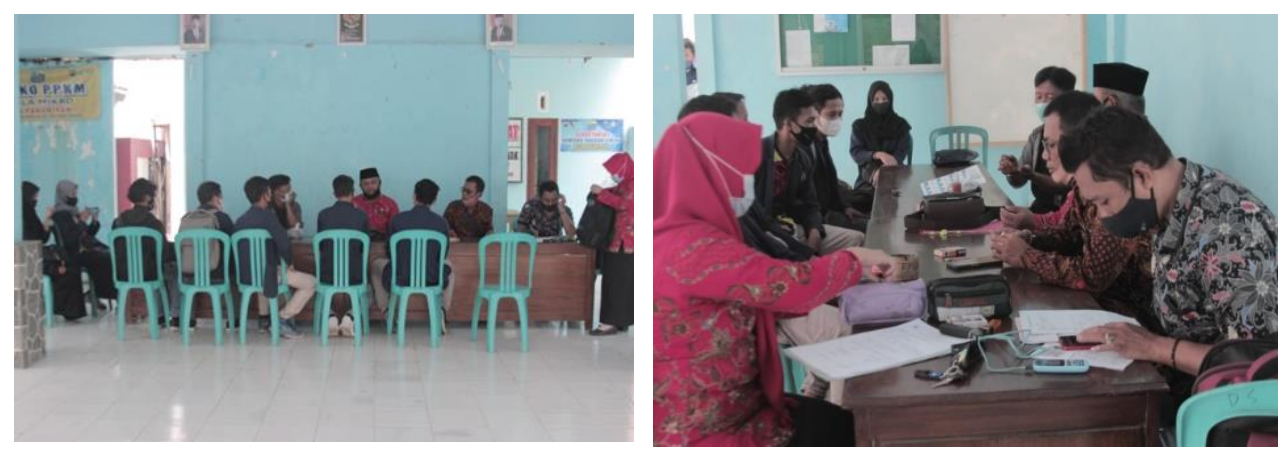

Gambar 2. Izin untuk melakukan kegiatan dan diskusi terkait kegiatan yang akan dilakukan 


\section{Pelaksanaan Kegiatan PKM}

Kegiatan ini dilakukan oleh tim PHP2D dengan membawa beberapa bahan dan alat. Untuk tempat dan alat-alat lain yang dibutuhkan tim PHP2D kami berkoordinasi dengan Bapak Carik desa Pakuniran.

a. Sosialisasi dan pelatihan tahap I Hari/Tanggal: Kamis 19 Agustus 2021 Pukul: 09.00-selesai

Tempat pelaksanaan: Rumah Bapak Carik, Bapak Salman Hasil kegiatan:

Kegiatan ini merupakan kegiatan sosialisasi sekaligus pelatihan pembuatan keripik dari pelepah pisang. Sebelum memulai pelatihan, tim PHP2D mensosialisasikan terkait apa saja manfaat pohon pisang terutama batang dan pelepah pohonnya. Cara mengolah pelepah pisang menjadi bahan yang harus disiapkan yakni pelepah pohon pisang yang sudah diiris tipis-tipis, kemudian rendam dengan air garam. Panaskan minyak, ambil menunggu minyak panas masukkan tepung beras, tepung terigu, penyedap rasa, bawang putih bubuk, air secukupnya adoni dan masukkan pelepah pisang yang sudah direndam didalam air selama 10-15 menit tersebut ke dalam adonan. Masukkan satu per satu pelepah pisang yang sudah tercampur dengan bumbubumbu tersebut ke dalam minyak yang sudah panas. Goreng hingga kecoklatan atau matang. Rasanya enak, gurih, dan renyah.

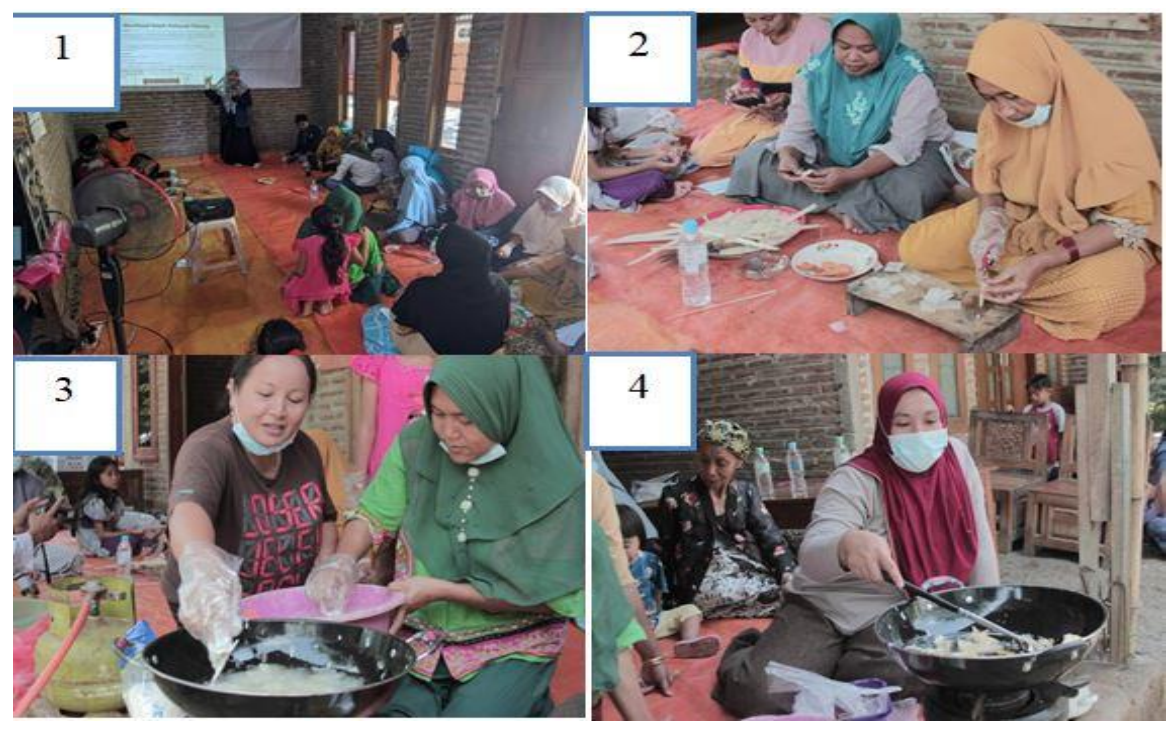


Keterangan:

Gambar 1 Sosialisasi terkait pemanfaatan batang dan pelepah pohon pisang I Gambar 2 pelatihan pemotongan pelepah pisang sebagai keripik dan hasil potongan langsung direndam dalam air garam | Gambar 3 pelatihan pencampuran pelepah pisang dengan adonan tepung dan bumbu | Gambar 4 pelatihan menggoreng keripik pelepah pisang

b. Sosialisasi dan pelatihan tahap II

Hari/Tanggal: Sabtu, 04 Agustus 2021

Pukul: 09-Selesai

Tempat: Rumah Bapak Carik, Bapak Salman

Hasil kegiatan:

Pada kegiatan ini tim PHP2D melakukan sosialisasi tentang cara mengolah pelepah pisang sebagai hand sanitizer, dan batang pisang menjadi jus yang menyegarkan. Adapun bahan yang diperlukan untuk membuat hand sanitizer alami dari pelepah pisang yakni pelepah pisang, air, kayu manis, saringan, dan botol spray ukuran $100 \mathrm{ml}$

Cara pembuatannya cukup mudah dan sederhana hanya perlu memotongnya kecil-kecil, kemudian di blender untuk diambil sarinya, saring dari ampasnya, rebus sari pelepah pisang hingga mendidih, tambahkan kayu manis, setelah dingin masukkan ke dalam botol spray sudah siap digunakan. Menurut penelitian dari siswa SMA Negeri 1 Tahunan Jepara yang dilakukan di laboratorium sekolah mereka karena berbahan dasar alami hand sanitizer ini hanya bertahan 6 bulan.

Untuk pembuatan jus juga sangat mudah kita hanya perlu menyiapkan batang pohon pisang yang sudah direndam dengan air garam semalaman, kemuian potong-potong kecil, masukkan ke dalam blender, tambahkan gula, madu, jeruk nipis/jeruk lemon, air, blender hingga halus, saring ampasnya, tuangkan ke gelas jangan lupa tambahkan es batu, dan siap disajikan. 


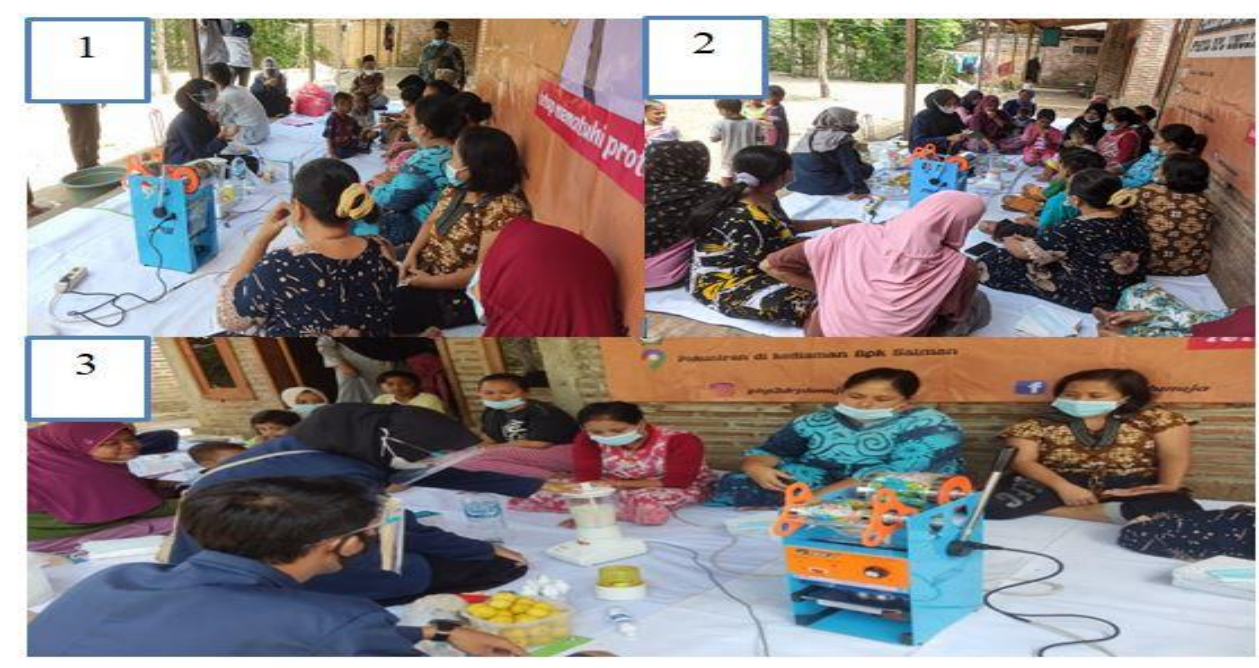

Keterangan

Gambar 1 Penjelasan tentang manfaat jus batang pisang | Gambar 2 Memotong batang pisang yang sudah direndam dengan air garam semalam | Gambar 3 Memblender batang pisang untuk dijadikan jus

c. Pembentukan Kelompok atau Mitra Baru

Dari adanya kegiatan sosialisasi dan pelatihan semangat IbuIbu untuk mengembangkan sangat besar sehingga meminta tim PHP2D untuk membuat kelompok untuk pengolahan batang dan pelepah pisang tersebut. Menurut mereka kegiatan ini sangat bagus di untuk meningkatkan kreativitas, inovasi, dan juga bisa menumbuhkan semangat kegiatan bermanfaat mengingat kegiatan PKK di Desa Pakuniran yang tidak berjalan.

Berikut ini nama-nama kelompok yang kami beri nama dengan kelompok PBP2D (Kelompok Pengolah Batang dan Pelepah Pisang Desa) yang telah terbentuk:

Tabel 5 Nama-Nama Kelompok PBP2D

\begin{tabular}{|l|l|l|l|}
\hline No & Nama & Keterangan & Alamat \\
\hline 1 & Hamina & Ketua & Dusun Duren \\
\hline 2 & Siti Romla & Sekretaris & Dusun Duren \\
\hline 3 & Siti Aisyah & Bendahara & Dusun Duren \\
\hline 4 & Umaria & Anggota & Dusun Duren \\
\hline 5 & Siska & Anggota & Dusun Duren \\
\hline 6 & Sri Wahyuni & Anggota & Dusun Duren \\
\hline
\end{tabular}




\begin{tabular}{|l|l|l|l|}
\hline 7 & Wiwik Lusiyah & Anggota & Dusun Duren \\
\hline 8 & Sholehatin & Anggota & Dusun Duren \\
\hline 9 & Suryani & Anggota & Dusun Duren \\
\hline 10 & Lilik & Anggota & Dusun Duren \\
\hline 11 & Subaida & Anggota & Dusun Duren \\
\hline 12 & Misrua & Anggota & Dusun Duren \\
\hline
\end{tabular}

d. Perbaikan Tempat untuk Produksi Sekaligus Jualan Offline

Pada awalnya untuk tempat penjualan secara offline akan diberikan box container jualan, namun setelah hasil diskusi dengan warga desa Pakuniran salah satu dari Ibu-lbu yang mengikuti program sosialisasi dan pelatihan memberikan saran untuk menjadikan warung tempat penjualan bakso miliknya yang tak terpakai sebagai tempat produksi sekaligus jualan.

Pertama tim PHP2D melakukan diskusi terkait perubahan yang akan dilakukan dan penambahan apa saja yang dibutuhkan, dari hasil diskusi tersebut maka diputuskan untuk menambahkan kayu pada tiang penyangga karena hampir roboh, menambahkan dinding kanan, kiri, dan belakang, serta penambahan pintu di bagian belakang. Untuk tambahan yakni aliran listrik dan lampulampu yang menarik di luar tempat penjualan. Kemudian tim PHP2D bergotong royong dengan warga sekitar untuk memperbaiki tempat yang akan digunakan sebagai tempat produksi sekaligus tempat penjualan tersebut. 


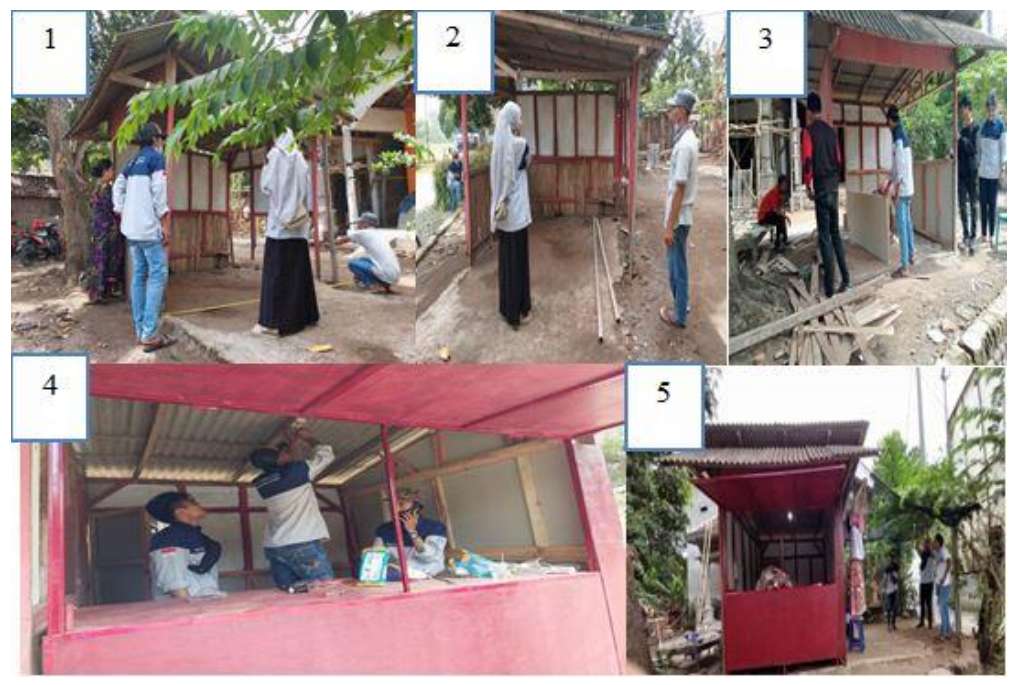

Keterangan:

Gambar 1 Pengukuran tempat | Gambar 2 Diskusi terkait renovasi Gambar 3 Gotong royong memperbaiki tempat | Gambar 4 Memasang listrik untuk lampu dan stop kontak di dalam warung | Gambar 5 Menambahkan lampu-lampu gantung di luar

e. Produksi Produk

Untuk produksi pertama Ibu-Ibu kelompok didampingi langsung oleh tim PHP2D RPL UNUJA, namun dari jumlah 12 orang yang ikut dalam proses produksi hanya 4 orang. Untuk kegiatan produksi berikutnya tim PHP2D memberikan amanah langsung kepada anggota kelompok untuk produksi tanpa pendampingan hal ini guna menumbuhkan kemandirian kelompok dan agar nanti ketika program sudah berakhir dapat diteruskan oleh kelompok ini (program berkelanjutan), namun sangat disayangkan kegiatan berikutnya tidak berjalan karena anggota kelompok tidak kompak untuk ikut produksi dan anggota kelompok juga memakai banyak alasan untuk tidak produksi sehingga kegiatan produksi tim PHP2D RPL UNUJA yang melanjutkan produksi tersebut. Dalam kegiatan produksi tim PHP2D RPL UNUJA berhasil memproduksi kurang lebih 100 pcs keripik pelepah pisang dan hand sanitizer. 


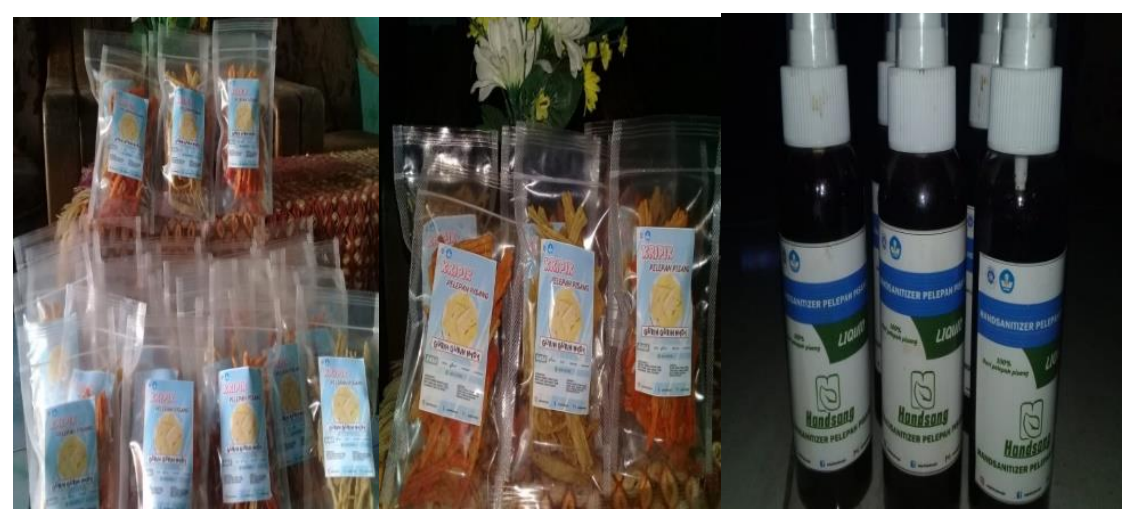

Gambar 3. Foto-Foto Produk Setelah Produksi

f. Pemasaran

Pemasaran dilakukan oleh tim PHP2D RPL UNUJA melalui WA masing-masing tim dan semua produk keripik pelepah pisang sudah laku terjual.

\section{Melakukan Evaluasi Kegiatan PKM}

Untuk mengetahui tingkat ketercapaian target dan mengindentifikasi pemasalahan serta kendala yang muncul dalam kegiatan PKM ini, maka tim melakukan kegiatan evaluasi. Hasil evaluasi ini selanjutnya akan dijadikan sebagai acuan dalam menyusun rencana tindak lanjut program. Ternyata semangat dalam mengembangkan usaha ini hanya diawal dan ketika didampingi. Jika dilepas dalam kata lain tenpa pendampingan agar terbentuk kelompok yang mandiri program berkelanjutan tidak terlaksana. Mitra tidak menjalankan program dengan banyak alasan yang juga menjadi penghambat kegiatan.

\section{Pembahasan}

Potensi sumber daya alam berupa pohon pisang di Desa Pakuniran sangat melimpah namun dalam pemanfaatannya hanya sebatas pada buah yang dijual secara langsung maupun diolah sebagai keripik pisang. Sedangkan untuk batang dan pelepahnya tidak dimanfaatkan oleh masyarakat, batang dan pelepah pisang ini dibuang begitu saja oleh masayarakat. Hal ini tentu juga disebabkan oleh rata-rata pendidikan masyarakat desa Pakuniran yang rendah sehingga guna untuk memberikan 
informasi terkait pengolahan batang dan pelepah pisang ini tim PHP2D RPL UNUJA mengadakan sosialisasi dan pelatihan pembuatan aneka produk olahan dari batang dan pelepah pisang.

Setelah diadakannya sosialisasi muncul semangat baru dari Ibu-lbu untuk meneruskan kegiatan karena menurut mereka hal ini sangat positif terlebih agar bisa membangun kembali kegiatan-kegiatan pada PKK yang sudah lama stagnan. Terbentuklah kelompok baru yang tim PHP2D RPL UNUJA beri nama dengan kelompok PBP2D atau kelompok Pengolah Batang dan Pelepah Pisang Desa yang berjumlah 12 orang dari Dusun Duren untuk meneruskan kegiatan setelah kegiatan tim PHP2D RPL UNUJA berakhir. Selain itu hasil dari sosialisasi dan pelatihan berupa pengetahuan warga Desa Pakuniran bahwa batang dan pelepah pisang bisa dimanfaatkan sebagai olahan makanan, minuman, dan antiseptik.

Selanjutnya tim PHP2D RPL UNUJA mendampingi Ibu-Ibu dalam memproduksi produk untuk produksi pertama, namun sangat disayangkan ketika tim PHP2D RPL UNUJA ingin membuat kelompok menjadi mandiri dengan dilepas tanpa pendampingan kegiatan tidak berjalan dan stagnan. Anggota kelompok yang sudah dijadikan mitra dan diajak untuk kerja sama tidak menjalankan kegiatan dengan banyak alasan, bahkan tidak ada titik temu untuk melanjutkan program kegiatan.

\section{Kesimpulan}

Hasil dari kegiatan pengabdian di desa Pakuniran ini adalah penambahan ilmu pengetahuan terkait pengolahan batang dan pelepah pohon pisang sebagai makanan, minuman, dan hand sanitizer. Terbentuknya kelompok ibuibu rumah tangga sebagai kelompok yang memproduksi olahan dari batang dan pelepah pisang tersebut yang kami beri nama dengan kelompok PBP2D (Pengolah Batang dan Pelepah Pisang Desa). 


\section{Daftar Pustaka}

Daryanto, Bercocok Tanam Buah-Bauahan, (Semarang CV. Aneka IImu, 20003), hlm.38

Nani Rosana Erman, Kreasi dari Pelepah Pisang dan Limbah Kelapa, (Surabaya: Tiara Aksa, 2007), hlm. 13.

Bambang Cahyono, PISANG (Usaha tani dan Penanganan Pasca Panen), (Yogyakarta : Kanisius, 2009) hlm. 09-10.

http://www.khasiat.co.id, diakses pada tanggal 02 April 2021, pukul 12.03 WIB.

Website desa Pakuniran, Kecamatan Pakuniran http://pakuniran.desa.id, diakses pada tanggal 06 April 2021, pukul 05.54

Badan Pusat Statistik Kabupaten Probolinggo, https://probolinggo.bps.go.id 